\title{
A Design of Partnership Model of Vocational High School with Business and Industrial World
}

\author{
Purnamawati \\ Engineering Faculty \\ Universitas Negeri Makassar \\ Makassar, Indonesia \\ purnamawati@unm.ac.id
}

\author{
Syahrul \\ Engineering Faculty \\ Universitas Negeri Makassar \\ Makassar, Indonesia
}

\begin{abstract}
This study aims to design a partnership model of Vocational High School with Business and Industrial World. The stages of model development used Plomp model design. The object of the research was in Vocational High School in Makassar City. The result of partnership model design based on need analysis and partnership problem consists of 7 (seven) components, i.e. (1) government ministry policy, (2) core strategies concept, (3) vocational high school policy, (4) industrial management, (5) the principle of ministry, (6) competence of graduates, (7) absorption of Vocational High School graduates. This model component was established in a systematic and structured way with the purpose of facilitating the activities of the partnership.
\end{abstract}

Keyword-- vocational high school, business, industrial world, partnership

\section{INTRODUCTION}

The advance of industry has developed very rapidly, especially in the application of technology and information in production process. The current age has turned to the digital age or industrial revolution 4.0, in which the demands and challenges of competence are expected to graduate from vocational education. Therefore, business world and industrial world (DUDI) must be balanced, in which there is no significant disparity between the competencies generated by vocational education and those expected by DUDI. Vocational High School (SMK) graduates as one source of productive workforce can meet market demands globally in improving the economic competitiveness of a country. Muhajir Effendy stated that SMK graduates should be ready to face the current global challenges [1].

Thoroughly, SMK and DUDI define partnership and its limitation as a cooperation in business relation, either directly or indirectly, based on mutual requirement, trust, strength and benefit, which involves perpetrators of Micro, Small, and Medium Business with Large Scale Business [2]. Partnership contains the understanding of friendship, cooperation, mutual reciprocity that helps each other [3] In this regard, the government has launched a revitalization of vocational education to increase skilled labor in the $21^{\text {st }}$ century. Hopefully, this can help to meet the demand of the $21^{\text {st }}$ century workplace for skilled manpower and also to produce individuals that will be equipped with saleable skills for employment and self-reliant. If this must be achieved, TVET (Technical vocational education and training) educational institutions must collaborate with the industry to bridge the skill gap [4].
Therefore, the partnership of SMK and DUDI needs to be redesigned since the implementation of partnership is only limited to the signing of Memorandum of Understanding $(\mathrm{MoU})$ for field industrial practice (Prakerin). Partnership program activities have not been followed up with an internship program that focuses on job skills with advancedtechnology equipments. [5] stated that the competency of SMK graduates often experience gaps with the competence of skills required by the world of work so that the absorption of SMK graduates in the world of work is still relatively low (misallocation of human resources).

The description becomes a strong foundation in designing a partnership model between SMK and DUDI with attention to the needs analysis and partnership program problems. In addition, the research results of several partnership models serve as a comparison and input to design a partnership model of SMK with DUDI. This study was conducted so that the flow of partnership between SMK and DUDI can be structured systematically. The results of [6] provided an illustration of the linkage between school and DUDI. Similarly, the results of [7] study illustrated the partnership development framework, and [8] indicated the partnership strategy designed by [9] and readopted by [10].

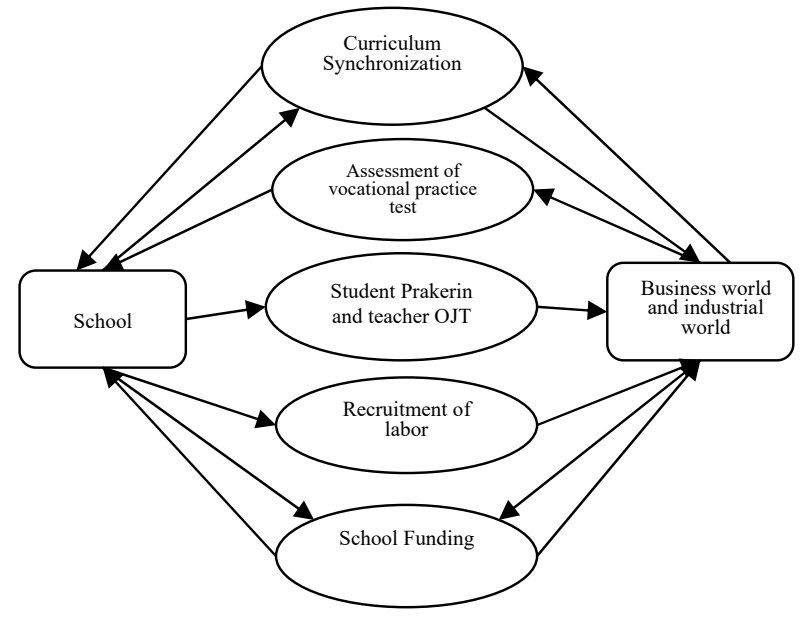

Fig. 1. Form of SMK Partnership with DUDI (Source: [6])

Fig.1. shows that: (1) The curriculum synchronization, School and labor users (DUDI) must synergize, especially in terms of learning materials so that between those who prepare the workforce, in this case school, a mutually beneficial cooperation, may give benefit to each other; (2) Prakerin or apprenticeship, business world and industrial world need to 
give wide opportunity to learners and teachers for work practice or internship so that the education actors in school can directly experience the work in DUDI. By doing so, the teacher can prepare the students in order to be able to compete to enter the world of work and learners get used to the work ethic in DUDI; (3) Recruitment of workers, it is time for laborers (DUDI) to recruit workers from their sources (schools) to reduce the occurrence of brokering that harms prospective workers. Precrein/recruitment funding, schools need to budget funds for the marketing of labor (students) because the vocational schools' task is not limited to the students only, but also to market their graduates or even conduct tracery tracking; (4) Model or form of partnership between DUDI and vocational school in partnership with SMK Muhammadiyah 2 Wuryantoro [6].

Based on the explanation of needs analysis and problem analysis, this research designed a partnership model of SMK with DUDI in improving the competency of SMK graduates by paying attention to core strategies and components of partnership theoretically and practically.

\section{METHOD}

The type of research used in answering the problem was development research through quantitative descriptive approach. This approach gained an idea of the design of SMK and DUDI partnership. The object of research was SMK in Makassar City and industries engaged in the field of electronics Engineering. The data was analyzed by using quantitative descriptive statistics.

\section{RESULT AND DisCUSSION}

\section{A. Partnership Model Analysis (AMK)}

SMK has an industrial practice program with the aim that students gain practical knowledge, skills and work experience, attitudes, responsibilities, and teamwork directly in the industry. The analysis of the partnership model that has been implemented in several SMKs is essentially the same, both the stages and components of the model. Description of the partnership as stated in the $\mathrm{MoU}$ as in Fig. 2., explained that the average content of MoU SMK and DUDI, namely: (1) Industry visits, (2) Field Industrial Practice, and (3) 100\% recruitment of labor. Furthermore, for competency and certification test about $83.33 \%$, teacher practice $38.89 \%$, and synchronization an validity of the curriculum $33.33 \%$.

However, the description has not been followed up with a program that can increase the competence of students in order to compete in the world of work, in general, in carrying out work directly in the industry. The contents of the MoU on the suitability of the areas of expertise that have been implemented using different models are tailored to the objectives of SMK and DUDI.

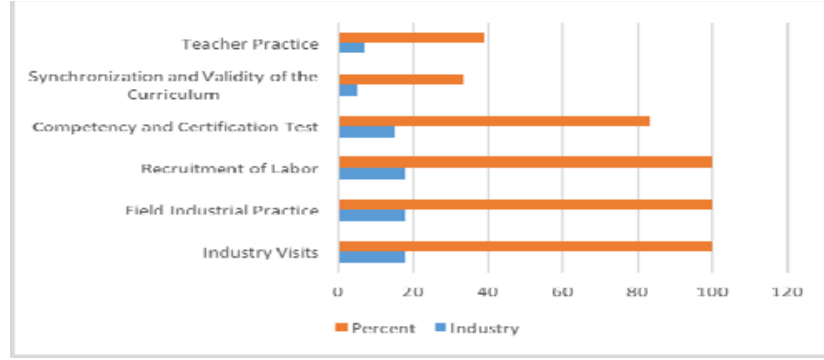

Fig. 2. Description of Contents of MoU on SMK with DUDI Partnership

\section{B. An Analysis of SMK and DUDI Partnership Problems}

The result of interview and completion of observation instrument showed some problems related to SMK and DUDI partnership:

First, the partnership between SMK and DUDI lied in the planned and agreed programs not being implemented properly. The programs offered are attractive and good, but not accomplished. This condition caused the partnership was only as a symbol in the form of MoU. Figure 2 describes the contents of MoU partnership with a number of activities to improve the competence of SMK graduates and assist the production process and services.

Second, there was no government policy with core binding concepts between both parties to implement the contents of the MoU well. Therefore, the implementation of Prakerin between SMK and DUDI was still limited to provide information about the process, stages, work preparation, tools needed in the production process, discipline, responsibility, and self-reliance. Prakerin students have not been fully involved in the production process.

Third, there was no win-win solution to the problem in SMK and DUDI. The industry run itself with its production technology and SMK carried out its own learning process with its practical equipment facilities. DUDI played a great role to develop the curriculum, providing a wise solution, as a place of competence test of learners, and sharing technology. In addition, SMK could obtain industrial equipment grants that can be used in practical learning at SMK.

Fourth, the DUDI has not provided a briefing on the competencies that SMKs should have in order to prepare Prakerin students before performing industrial work. SMK has not routinely and continuously invited DUDI as guest teacher or practitioner who can give knowledge about DUDI condition, technology and competence that need to be considered in study practice.

Fifth, training for teachers with on-job training programs has not been implemented optimally. Teachers need to update their knowledge and skills with new experiences. Working equipment and production process continue to grow which encourages teachers to wastage practical knowledge in DUDI, so that in the learning process, teachers can clearly describe the conditions that will be done by students in DUDI.

Sixth, the management of the implementation of partnership has not gone well. Especially Prakerin activities of 
learners in DUDI. Management is the planning, implementtation, and evaluation of Prakerin activities. During this time, the management of the partnership went the way it was, because Prakerin is only part of the curriculum and learning programs that must be done. The programming plan was not well drafted to impress the demands of the curriculum rather than the industry demands. Likewise, the evaluation that was carried out only in the form of records, did not make any improvements to the deficiencies occurred during the activity or completed by Prakerin activities.

\section{Partnership Design of SMK and DUDI}

Designing a partnership model of SMK and DUDI with attention to theoretical partnership patterns and needs analysis and problems. Several indicators are important as model components in the analysis to produce a feasible partnership designin which flow data is used in achieving the objectives of the partnership. The partnership model design has 7 (seven) components built based on needs analysis and partnership problem of SMK with DUDI. The components of the partnership are: (1) government ministry policy, Government policy in partnership emphasizing both parties can implement the contents of the MoU by taking into account the phases of the agreed programs, (2) core strategies concept explaining the steps in implementing the contents of MoU with 5Cs (Five core strategies), (3) vocational high school policy, The SMK and DUDI policy through the MoU contains programs that must be implemented and mutually agreed upon, (4) industrial management in regard to planning, implementation and evaluation, (5) the principle of ministry, Principles of partnership and partnership activities adjusted to the MoU between parties, (6) competence of graduates, expected competence is a competency criterion adjusted to DUDI expectation, (7) absorption of Vocational High School graduates, The absorption of SMK graduates describes the acceptance of prakerin participants for internship and work contract with DUDI.

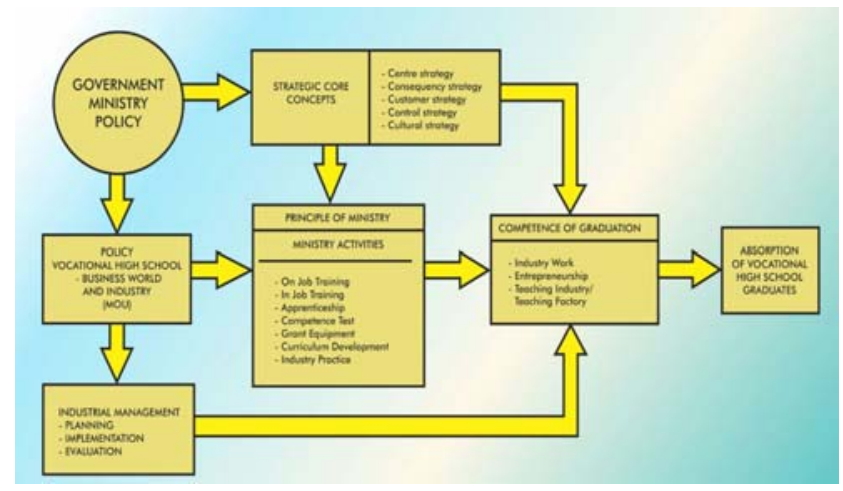

Fig. 3. Model Design Of SMK and DUDI Partnership

The partnership that exists between SMK and DUDI has an enormous impact in improving the competency of SMK graduates. Cooperation between the two parties through the $\mathrm{MoU}$ has the concept of mutual benefit, mutual trust and mutual strengthening. The partnership model established between SMK and DUDI develops well with government policy through core strategies concept. [6] stated that the partnership between vocational education and private sector should be supported by the government, such as cost support as one of the strategies to achieve success in management and revitalization in a country. [11] stated that the lack of achievement of the SMK partnership policy targets was a result of the lack of mechanisms implementation that have been previously designed. This indicates a lack of matching outcomes with existing implementation plans. Therefore, an indepth analysis of the implementation process from the beginning to the outcome and its final impact is required.

[12] stated that a person is required to have the ability to cooperate and deal with others, on the basis of a combination of ability to work together and communicate. [5] explained that the partnership model of SMK-DUDI is expected to be a collaboration that can facilitate the development of professional competence and bridge the competency gap of SMK graduates with the need of job market. The results of [13] showed that the overall effectiveness of Prakerin management in SMK Kota Yogyakarta has very effective criteria. Aspects of planning and execution resulted in high gap points, namely: (1) the Prakerin group officials in schools are less than four persons, (2) the business world and the industrial world around the school are not always relevant to the program (4) the relevance of the teacher counsellors' skill program with the underguided students, (5) the implementation of the scheme is still often hampered by student discipline, (6) the working group still finds Prakerin participants who completed their Prakerin activities did not match the time allocation. Furthermore, [14] in his research showed that: (1) The role of DUDI has positive and significant influence with coefficient of 0,544; and (2) The role of DUDI, the implementation of Dual System Education (PSG) and the characteristics of vocational students have an effect on the adaptive power of SMK students positively and significantly with the coefficients of each factor of $0.202 ; 0.318$ and 0.333 .

Illustration of the emerging findings is the extent to which curriculum documents have reflected teaching practices that embed authentic workplace knowledge in school programs. The analysis of two senior subjects (Years $11 \& 12$ ) developed in collaboration with industry representatives revealed that while they provide opportunities for students to learn a range of relevant concepts, the extent to which they provide experiences of the workplace and simulate workplace cultures and skills was still limited. The scope of knowledge transfer appeared constrained by teacher knowledge and the practical experiences that teachers themselves had on technical workplace practice and culture [15]. Implications are that industry-school partnership stakeholders would benefit from applying partnership principles regarding implementation and management to ensure the sustainability of partnerships [16].

\section{CONCLUSION}

The design of SMK and DUDI partnership implements 7 (seven) integrated components: (1) government ministry policy, (2) core strategies concept, (3) vocational high school policy, (4) industrial management, (5) the principle of ministry, (6) competence of graduates, (7) absorption of Vocational High School graduates. The components of SMK model design 
with DUDI are systematically integrated to produce competency of SMK graduates.

\section{REFERENCES}

[1] Kuwado, Febian Januarius. "Mendikbud Ingin Pendidikan Berdaya Saing Internasional". Kompas, 11-08-2016. https://nasional.kompas.com/read/2016/08/11/13543341/mendikbud.ingi n.pendidikan.kejuruan.berdaya.saing.internasional.

[2] Peraturan Pemerintah RI Nomor 17 Tahun 2013 tentang Usaha Mikro, Kecil dan Menengah.

[3] Kuntoro, Sodiq. "Kemitraan Sekolah. Workshop Strategi Pengembangan Mutu Sekolah Bagi Kepala Sekolah dan Pengawas Sekolah diselenggarakan Prodi S2 Manajemen Pendidikan dan S3 Ilmu Pendidikan, 2010". http://staff.uny.ac.id/sites/default/files/130275878/ KEMITRAAN\%20SEKOLAH\%20pak\%20sodiq.pdf

[4] Oviawe, Jane Itohan., Uwameiye, Raymond., Uddin, Patrick S. O. Bridging Skill Gap to Meet Technical, Vocational Education and Training School-Workplace Collaboration in the $21^{\text {st }}$ Century, International Journal of Vocational Education and Training Research. Vol. 3, No. 1, 2017, pp. 7-14. doi: 10.11648/j.ijvetr.20170301.12. http://article.sciencepublishinggroup.com/pdf/10.11648.j.jjvetr.2017030 1.12.pdf.

[5] Mulyatiningsih, Endang., Sugiyono, \& Purwanti, Sutriyati. "Model partnership guru produktif SMK dengan dudi untuk meningkatkan kemampuan teacherpreuner". Laporan Penelitian Strategis Tahun I. Yogyakarta: UNY, 2014.

[6] Ixtiarto, Bambang \& Sutrisno, Budi. "Kemitraan Sekolah Menengah Kejuruan Dengan Dunia Usaha dan Dunia Industri (Kajian aspek Pengelolaan Pada SMK Muhammadiyah 2 Wuryantoro Kabu-paten Wonogiri)", Jurnal Pendidikan Ilmu Sosial, Vol. 26, pp. 57- 69, Juni 2016. http://journals.ums.ac.id/index.php/jpis/article/view/2130/1568

[7] Rasto. "Keniscayaan kemitraan sekolah menengah kejuruan (SMK) dengan dunia usaha dan industri (DUDI) (Suatu Tinjauan Filosofis dan Empiris)". Disampaikan pada kegiatan Bimbingan Teknis Program Pemerataan Mutu Keahlian bagi Guru SMK melalui kerjasama dengan DUDI yang diselenggarakan oleh Subdit PTK SMK. Bogor, 28-30 April 2014.

[8] Helmy, Abdullah. "VET Training and Industry Partnership: A Study in East Java, Indonesia", 2014. http://vuir.vu.edu.au/28814/1/Helmy\% 20Abdullah.pdf.

[9] Lendrum, T. "The Strategic Partnering Handbook 4edn", McGraw-Hill, Australia, 2003.

[10] Callan, VJ \& Ashworth, "P. Working together: Industry and VET provider training partnerships", NCVER, Adelaide, SA, 2004. https://files.eric.ed.gov/fulltext/ED495165.pdf.

[11] Abbas, Muhammad Yusuf. "Model implementasi kebijakan kemitraan untuk meningkatkan mutu dan relevansi lulusan SMK", 2015. https://myunusabbas.wordpress.com.

[12] Kuswana, Sunaryo, Wowo. "Dasar-dasar Pendidikan Vokasi \& Kejuruan". Bandung: Alfabeta, 2013.

[13] Permana, Putut Said \& Sukoco. "Efektifitas Manajemen praktik Kerja industry di Sekolah Menengah Kejuruan Kota Yogyakarta". Jurnal Akuntabilitas Manajemen Pendidikan Volume 5, N0.2, September 2017 (199-211). https://www.researchgate.net/publication/320309230 Efektivitas_manajemen_praktik_kerja_industri_di_Sekolah_Menengah_Keju ruan_Kota_Yogyakarta.

[14] Maskan, Mohammad \& Suparlan. "Model struktural dimensi peran dunia usaha/industri, aplikasi pendidikan sistem ganda dan karakteristik siswa dalam membentuk daya adaptif kerja siswa SMK di Malang Raya".2012. http://menulisbersamaaswir.blogspot.co.id/2011/09.

[15] Watter, James., Hay, Stephen., Dempster, Neil., Pillay, Hitendra. School Industry Partnerships: An Innovative Strategy For Vocational Education. Conference:ECER 2013, Creativity and Innovation in Educational Research, Vocational Education and Training (VETNET). 2013. http://www.eera-ecer.de/ecer-

programmes/conference/8/contribution/22028/

[16] Pillay, Hitendra., Watters, James J., Hoff, Lutz., Flynn, Mattew. Dimensions of effectiveness and efficiency: a case study on industry- school partnerships, Journal of Vocational Education \& Training, 66:4, 537553, DOI: 10.1080/13636820.2014.961524. (2014). https://eprints.qut.edu.au/78025/4/78025.pdf 